\title{
Tıp fakültesi öğrencilerinin 2P:4P el parmak uzunluk oranları ile kişilik özellikleri arasındaki ilişkinin incelenmesi
}

\author{
Nazan Karaoğlu ${ }^{*} \odot$, Gülay Açar ${ }^{2} \odot$ \\ ${ }^{1}$ Prof. Dr. | Necmettin Erbakan Üniversitesi Meram Tıp Fakültesi Aile Hekimliği Anabilim Dalı, Konya - Türkiye \\ ${ }^{2}$ Dr. Öğr. Üyesi | Necmettin Erbakan Üniversitesi Meram Tıp Fakültesi Anatomi Anabilim Dalı, Konya - Türkiye
}

* Sorumlu Yazar / Corresponding Author:

Gülay Açar

Necmettin Erbakan Üniversitesi Meram Tıp Fakültesi Anatomi Anabilim Dalı 42090 Akyokuş - Meram, Konya / Türkiye E-posta: gacar@erbakan.edu.tr

\section{Öz}

İnsan vücudu ve hastalık semptomlarının genetik ve sosyokültürel yapıya bağlı olarak sürekli farklılık gösterdiği son yıllarda medikal antropoloji alanında yapılan çalışmalarda ortaya konmuştur. Benzer olarak hekimin kişilik özellikleri ve toplumun sosyokültürel yapısına bağlı değişimleri hekimlik pratiği için önemlidir. Prenatal cinsiyet hormonlarının hem kişilik özellikleri hem de elin işaret (2. parmak) ve yüzük (4. parmak) parmaklarının uzunluk oranları (2P:4P) ile ilişkili olduğu söylenmektedir. Bu çalışmada, preklinik tıp öğrencilerinde cinsiyet hormonlarının etkisine bağlı ortaya çıkan 2P:4P oranı ile pozitif-negatif duygulanımlar arasındaki ilişkinin incelenmesi amaçlandı. Çalıșmaya katılan 493 tıp öğrencisinin (199 erkek, 294 kadın) boy, kilo ve iki elin 2. ve 4. parmak uzunlukları ölçülerek 2P:4P oranı bulundu. Ayrıca sosyodemografik bilgilerle PozitifNegatif Duygu Ölçeği (PANAS) ve Beș Faktörlü Kişilik Envanteri Kısa Formu (BFKE-K)'nu içeren anket uygulandı. Boy, kilo ve vücut kitle indeksi değerleri erkeklerde, her iki el 2P:4P oranları ise kadınlarda anlamlı düzeyde yüksek bulundu $(p<0,001)$. Sağ el 2P:4P oranı ile PANAS- Pozitif ve Negatif Duygu puanları arasında negatif yönde zayıf korelasyon $(r=$ $0,106, p=0,018 ; r=-0,087, p=0,052)$ ve BFKE-K puanı arasinda pozitif yönde zaylf korelasyon $(r=0,090, p=0,045)$ saptandi. Sağ ve sol el $2 \mathrm{P}: 4 \mathrm{P}$ oranlarının uyumluluk puanı ile pozitif korelasyon $(r=0,126, p=0,005$; $r=0,091, p=0,043)$ gösterdiği bulundu. Dışa dönüklük puanı 3. sınıf öğrencilerinde yüksekti ( $p=0,006$ ve $p=0,002$ ). Çalışmamızda olumlu kişilik özellikleri ve pozitif duygulanım puanı erkeklerde kızlara göre ve 3. sınıf öğrencilerinde ilk iki yıl öğrencilerine göre anlamlı düzeyde yüksek bulundu. Bu çalışmanın oluşturduğu farkındalıklar, hekimin kişilik özelliklerine uygun daha iyi bir tıp eğitimi almasını sağladığı gibi, seçtiği uzmanlık dalında daha etkin tedavi çözümleri üretmesine yardımcı olabilir.

The relationship between the length ratio of the index and ring fingers (2D:4D) and personality traits in medical students

\section{Abstract}

Recent studies in medical anthropology have revealed that the buman body and disease symptoms constantly vary depending on the genetic and sociocultural structure. The physician's personality traits and their variations due to the sociocultural structure are important for the practice of medicine. Prenatal sex hormones are associated with both personality traits and the length ratios (2D:4D) of the index and ring fingers of the hand. In this study, we aimed to investigate the relationship between 2P: 4P ratio depending on sex hormones and positive-negative emotions in preclinical medical students. The height, weight, $2^{\text {nd }}$ and $4^{\text {th }}$ finger lengths of both hands and 2D:4D ratios of 493 students (199 males, 294 females) were determined. A questionnaire including the Positive-Negative Emotion Scale (PANAS) and the Five-Factor Personality Inventory Short Form (FFPI-S) with sociodemographic information was applied. The height, weight, body mass index values were significantly bigher in men, and 2D:4D ratios were significantly higher in women $(\mathrm{p}<0.001)$. Negative correlation between the right hand $2 D: 4 D$ ratio and Positive and Negative Emotion $(\mathrm{r}=-0.106, \mathrm{p}=0.018 ; \mathrm{r}=-0.087, \mathrm{p}=0.052)$ and positive correlation between the FFPI-S $(\mathrm{r}=0.090, \mathrm{p}=0.045)$ were determined. $2 \mathrm{D}: 4 \mathrm{D}$ ratios of both hands positively correlated with the compatibility $(\mathrm{r}=0.126, \mathrm{p}=0.005, \mathrm{r}=0.091$, $\mathrm{p}=0.043)$. Extraversion score was higher in $3^{\text {rd }}$ grade students $(\mathrm{p}=0.006$ and $\mathrm{p}=0.002)$. Positive personality traits and emotion scores were higher in boys and $3^{\text {rd }}$ grade students. The awareness created by this study can belp the physician to receive a better medical training compatible with their personality traits and to produce more effective treatment process in their expertise.

Key Words: 2D:4D ratio, personality traits, medical anthropology, PANAS scale, medical student

Anahtar Sözcükler: 2P:4P oranı, kişilik özellikleri, medikal antropoloji, PANAS ölçeği, tıp öğrencisi 


\section{Giriş}

İnsanda sağlık ve hastalık değerlendirmesini sadece biyomedikal bakış açısıyla değil, sosyokültürel ve fizikî etkileşimlerini de kapsayacak şekilde daha geniş bir perspektifte ele alan medikal antropoloji, antropoloji bilim dalının bir alt disiplinidir. Son yüzyılda ortaya çıkan medikal antropoloji, insan bedenini evrensel kabul etmekten ziyade, içinde bulunulan toplumun çevresel, genetik ve kültürel özelliklerinden etkilenen bir biyolojik oluşum olarak tanımlarken biyotıp alanındaki hekimlere de bir dizi etik sorumluluklar yükler (Can, 2017; Koç ve Çetli, 2019).

Antropolojinin alt dallarında, özellikle adlî antropolojide kimliklendirme sürecinin ilk aşamasını oluşturan etnik kimlik, yaş, boy ve cinsiyet tayini çalışmalarında kullanılan antropometrik yöntem; canli, kadavra ve radyolojik örnekler üzerinde (özellikle yüz bölümü ile alt ve üst ekstremiteler) belirli anatomik noktalar arasinda yapilan direkt ve indirekt metrik ölçümleri kapsamaktadır. Basit, maliyeti düşük ve noninvaziv bir yöntem olan antropometrik ölçümler, tüm gelişim aşamalarında birey ve toplumun sağlık, güç, hareket, beslenme ve refah düzeylerini yansitır ve halk sağlığının optimum düzeylere çıkarılmasına yönelik yapılan klinik uygulamalar için veri tabanı oluşturur (Akın vd., 2017; Ulcay ve Kamaşak, 2020). El ve ayak boyutlarının osteolojik ve radyolojik incelemesi (epifizin kaynaşma yaşı farklılık gösterir) sonucu elde edilen veriler; özellikle el parmak izleri, uzunlukları ve birbirine oranlarının $1 \mathrm{rk}$, cinsiyet, yaş ve boy tahmini ile parçalanmış, parçalanmamış insan kalıntılarının belirlenmesinde sıklıkla kullanılan ve güvenilirliği yapılan araştırmalarda da gösterilmiş antropometrik ölçümlerdir (Akın vd., 2017; Koç ve Çetli, 2019).

Gebeliğin 2-3. aylarında fetüste salgilanmaya başlayan testosteron (erkek) ve östrojen (kadın) adı verilen hormonlara bağlı olarak cinsiyet farklılaşması ortaya çıkar. Son yıllarda yapılan çalışmalarda prenatal testosteron hormonunun erkeklerde dördüncü parmak (yüzük parmağı: 4P) ve östrojen hormonunun ise kadınlarda ikinci parmağın (işaret parmağı: $2 \mathrm{P}$ ) diğerine göre daha uzun olmasina neden olduğu ve el 2P:4P oranının erkekte ve özellikle sağ elde daha düşük olduğu tespit edilmiştir (Putz vd., 2004; Malas vd., 2006; Manning, 2011). Lutchmaya ve ekibi (2004) 2. trimester'da rutin amniosentez uygulanan 33 gebenin fetuslarında fetal testosterone ve östradiol seviyesini ölçmüşlerdir. Doğumdan 2 yıl sonra aynı çocuklarda 2. ve 4. el parmak uzunluklarını ölçüp el 2P:4P oranını tespit etmişlerdir. Elde ettikleri ölçüm değerlerinden sağ el 2P:4P oranı ile fetal cinsiyet hormonu oranları arasında istatistiki açıdan önemli negatif ilişki tespit etmişlerdir (Lutchmaya vd., 2004).

Prenatal cinsiyet hormon düzeylerinin insanda sadece fiziksel antropometrik özellikler üzerinde değil, kişilik özellikleri ve yeteneklerin oluşumunda da etkin rol oynadığ1 gösterilmiştir. Özellikle yeteneklerin gelişmesinde major rol oynayan yatkınlık da hormonlara bağlı gelişmektedir. Literatürde el parmak uzunlukları ve 2P:4P oranının, androjen duyarlılı̆̆ının güvenilir bir göstergesi olduğu ve bireylerin bilişsel yetenekleri, duygusal zekâ ve öğrenme stilleri, kişilik özellikleri ve yatkın oldukları mesleki alanların belirlenmesinde de bir ölçüt olarak kullanılabileceği bildirilmiştir (Cebe ve Varol, 2013; Özek, 2017). İlk olarak Wilson'un (1983) 985 kadın üzerinde yaptığı çalışmada; kendine güvenme kişilik özelliği ile el 2P:4P oranı arasında zayıf negatif korelasyon tespit edilmiştir (Wilson, 1983). Fink ve ekibi (2004) 50 erkek, 70 kadın üzerinde beş faktör kişilik envanteri (5FKE) anketini uygulamışlar ve ölçtükleri el 2P:4P oranları ile karşılaştırmışlardır (Fink vd., 2004). Mitsui ve ekibi (2016) 8 yaşındaki 1631 (842 erkek, $779 \mathrm{kız}$ ) çocukta el 2P:4P oranını ölçüp okul öncesi aktivite envanteri testini uygulamıslar ve erkek ya da kız kardeşinin olması gibi sosyal faktörler etkili olsa da prenatal hormon düzeylerinin erkeksi tip dimorfik beyin gelişimi ve davranışlar üzerinde en etkin faktör olduğunu rapor etmişlerdir (Mitsui vd., 2016).

İnsanın kişilik özelliklerinden söz edilirken genelde kişiliği belirleyen beş temel faktörden sözedilir. 5FKE, dişadönüklük, duygusal dengelilik, uyumluluk, deneyime açıklık (zekâ/hayal gücü) ve sorumluluk alt boyutlarından oluşan ve kişiliğin değerlendirilmesinde sıklıkla kullanılan bir yaklaşımdır (Goldberg, 1992). Lippa (2006) 2000 üniversite öğrencisinin el 2P:4P oranını ölçüp 5FKE anketini uygulamışlar (Lippa, 2006). Burton ve ekibinin (2013) yaptığ̀ çalışmada; el 2P:4P oranı değerleri ile uygulanan 5FKE anket sonuçları karşılaştırılmış ve 2P:4P oranı erkeklerde daha düşük bulunarak açı olma kişilik özelliğinin kadınlarda istatistiki açıdan önemli oranda yüksek olduğu rapor edilmiştir (Burton vd., 2013). Cebe ve ekibi (2013) "Testosteron seviyesi sayısal sözel yatkınlı̆̆1, el 2P:4P oranı ise testosteron seviyesini belirlemede önemli bir etkendir" kurallarına dayanarak Delphi ve Firebird veri tabanında hazırladıkları uzman sisteme çektikleri el fotoğraflarını yüklemişler ve sağ el 2P:4P oranı ile sayısal-sözel-eşit ağırlık yatkınlık parametreleri arasında anlamlı bir ilişki olduğu sonucuna varmışlardır (Cebe ve Varol, 2017). Aksu ve ekibinin (2010) 63 (48 kadın, 15 erkek) paramedik program öğrencisi üzerinde yaptıkları çalışmada her iki elin 2P:4P oranı ölçüm verileri ile Melbourne Karar Verme Ölçeği, Schutte Duygusal Zeka Ölçeği, İş Ortamı Stres Ölçeği, Empati Ölçeği ve 5FKE test sonuçlarını karşılaştırmışlardır (Aksu vd., 2010). Koç ve Çetli (2019) 204 (102 kadın, 102 erkek) üniversite öğrencisinin yer aldığ çalışmalarında elde ettikleri sağ sol el 2P:4P oranı, yüz uzunluğu ve genişliği, 
boy ve ağırlık ölçüm verileri ile Buss-Perry saldırganlık ölçeği uygulama sonuçları arasında anlamlı bir ilişki bulamamışlardır (Koç ve Çetli, 2019).

Hasta açısından hekim, sağlık sorunlarını her türlü özeliyle paylaştığı, onu en iyi anlayan ve tedavi etme yeteneğine en çok inandığı kişidir denilebilir. Bu durum, hekimlik ile ilgili çalışmaları, medikal antropoloji alanında önemli bir konu haline getirmektedir (Can, 2017). Son yıllarda maliyeti düşük ve basit teknikler kullanılarak ölçülen el 2P:4P oranları ile deneysel psikoloji, spor ve sağlık bilimleri alanlarında çeşitli hastalıkların risk gruplarının tayini, tanı ve takibi arasındaki ilişki oldukça önemli bir çalışma konusu haline gelmiştir. Özkan ve ekibi (2018) 400 Tip-2 Diyabet hastası ve 400 sağlıklı birey üzerinde bazı antropometrik ölçümleri (boy, ağırlık, el 2P:4P oranı) karşılaştırmışlar ve 2P:4P oranının doğumdan sonraki diyabet hastalığı gelişme risk düzeyinin belirlenmesinde kullanılabilecek bir ölçüt olduğunu rapor etmişlerdir (Özkan vd., 2018). Demirci ve Öztop (2015) 8-15 yaş aralığında dikkat eksikliği hiperaktivite bozukluğu (40 erkek) ve kontrol grubu (40 erkek) olan 80 birey üzerinde yaptıkları çalışmada hasta çocuklarda agresyon seviyeleri ile parmak oranı arasında negatif bir korelasyon olduğunu bildirmisslerdir (Demirci ve Öztop 2015). Vladeanu ve ekibi (2014) Alzheimer hastas1 ve kontrol grubu olarak 20'şer hasta üzerinde yaptıkları çalışmada düşük parmak oranına sahip bireylerin Alzheimer'a yakalanma riskinin daha yüksek olduğunu rapor etmişlerdir (Vladeanu vd., 2014).

Literatür bilgilerinden yola çıkılarak 5FKE kişilik özelliklerinin öğrencilerin akademik performanslarını belirlemede kullanılabileceği ve faydalı sonuçlar elde edilebileceği ileri sürülebilir. Bilindiği üzere hekimin kişilik özellikleri ve duygulanımlarının yönü de akademik başarının yanısıra hekim-hasta, hekim-hekim ve hekimtoplum ilişkileri açısından da çok önemlidir. Literatürde tıp fakültesi öğrencilerinin kişilik özellikleri ile yapılmış çok az sayıda yayın mevcuttur ve olan yayınlar da sağ ve sol el 2P:4P oranları ile pozitif-negatif duygulanım arasındaki ilişkiyi sorgulamamıştır. Oysa hekimlik pratiğine en çok yansiyan ve belki de erken dönemde tespit edebilirsek eğitimle düzeltebileceğimiz alanlardan biri budur. Preklinik tıp öğrencileri üzerinde yapılan bu çalışmada, cinsiyet hormonlarının 2P:4P oranı üzerindeki etkinliğinin ve bu oran ile pozitif-negatif duygulanımlar arasındaki ilişskinin incelenmesi amaçlanmıştır.

\section{Gereç ve yöntem}

Kesitsel, tanımlayıcı tipteki bu çalışma 2017-2018 akademik yllında Tip Fakültesi'nde okumakta olan 1. sinıfta 255 (159 kadın, 96 erkek); 2. sinıfta 187 (107 kadın, 80 erkek) ve 3. sınıfta 51 (29 kadın, 22 erkek) öğrenci üzerinde yapılmıştır. 18-30 yaş aralığında 493 preklinik tıp öğrencisinin yer aldığı çalışmaya sağ veya sol elinde sakatlık, parmak eksikliği veya eline cerrahî müdahale yapılmış ögrenciler ile yabancı uyruklu öğrenciler (uygulanacak ölçekler iyi bir dil hâkimiyeti gerektirdiğinden) dâhil edilmedi. Araştırmanın etik onayı Necmettin Erbakan Üniversitesi Meram Tip Fakültesi İlaç ve Tıbbi Cihaz Dışı Araştırmalar Etik Kurulu'ndan alınd1 (Karar No: 2018/1218).

Bilgilendirilmiş onam formunu imzalayan gönüllü öğrenciler çalışma için tasarlanmış anket formunu doldurup her iki el 2. ve 4. parmak uzunluklarının ölçülmesi için Anatomi Anabilim Dalı öğrenci laboratuvarına alındi. Önceki çalışmalarda önerilen doğrultuda metakarpofalangeal eklemin volar (ön, el ayası) yüzündeki proksimal kıvrımdan parmak ucuna kadar dijital kumpas yardımıyla ölçüldü. Ayrıca, $50 \mathrm{~cm}$ yükseklikten dijital fotoğraf makinesi ile çekimler yapılıp ImageJ 1.50 sürümü dijital ölçüm programı kullanılarak ikinci bir ölçüm daha yapıldı. Yapılan iki ölçümde elde edilen değerlerin ortalaması belirlenip her iki el 2P:4P oranları tespit edildi. Ayrıca dijital baskül yardımıyla boy ve kilo ölçümü yapıldı ve vücut kitle indeksi (VKİ=kg/ $\mathrm{m}^{2}$ ) hesaplandi.

Çalışma için hazırlanan anket formu kısa sosyodemografik bilgiler ile Gençöz (2000) tarafindan Türkçeye uyarlanıp, geçerlik güvenilirlik çalışması yapılmış olan "Pozitif-Negatif Duygu Ölçeği (PANAS)" ve Goldberg tarafindan geliştirilmiş olan "Büyük Beş Kişilik Özelliğì" temelinde "Beş Faktörlü Kişilik Envanteri Kisa Formu (BPKE-K)"nu içermektedir (Goldberg, 1992; Gençöz, 2000).

\section{Pozitif-Negatif Duygu Ölçeği (PANAS)}

On pozitif, 10 negatif duygu ifadesi içermektedir. Beşli Likert ile 1 (Çok az veya hiç) - 5 (Çok fazla) arasında puanlanmaktadır. Ölçekten alınabilecek en az ve en çok puanlar her bir duygu için 10-50 puan arasında değişmektedir (Gençöz, 2000).

\section{Beş Faktörlü Kişilik Envanteri Kısa (BFKE-K) Formu}

John ve Srivasta (1999) tarafindan geliştirilmiş olan 44 maddelik ölçekte düz ve ters kodlanan ifadeler vardır. "T" ters ifadeyi anlatmaktadır. Ölçekte Dışadönüklük; 1, 6T, 11, 16, 21T, 26, 31T, 36; Uyumluluk: 2T, 7, 12T, 17, 22, 27T, 32, 37T, 42; Sorumluluk: 3, 8T, 13, 18T, 23T, 28, 33, 38, 43T; Duygusal Dengelilik: 4, 9T, 14, 19, 24T, 29, 34T, 39; Deneyime açılılk (zekâ/hayal gücü): $5,10,15,20,25,30,35 \mathrm{~T}, 40,41 \mathrm{~T}, 44$ ifadeleri ile alt boyutlara ayrilmaktadır (John ve Srivasta, 1999).

\section{Istatistiksel analiz}

Çalışmada elde edilen verilerin analizleri SPSS 22.0 programı kullanılarak yapıldı. Tanımlayıc1 istatistikler için say1, yüzde, ortalama (Ort.) ve standart sapma (SS); sayısal değişkenler için parametrik testler (Student 
Tablo 1. Katıllmcılarn boy, kilo, vücut kitle indeksi, el parmak ölçümleri ve demografik özellikleri

\begin{tabular}{|c|c|c|c|c|}
\hline & Kadın & Erkek & Toplam & \\
\hline & Ort. (SS) & Ort. (SS) & Ort. (SS) & $p$ \\
\hline Yaş & $19,65(1,43)$ & $19,91(1,62)$ & $19,76(1,52)$ & \\
\hline Boy (m) & $1,64(0,05)$ & $1,77(0,06)$ & $1,69(0,08)$ & \\
\hline Kilo (kg) & $57,99(8,24)$ & $75,84(12,35)$ & $65,16(13,35)$ & \\
\hline VKI & $21,41(2,83)$ & $23,85(3,89)$ & $22,39(3,50)$ & $<0,001$ \\
\hline \multicolumn{5}{|l|}{ E1 parmak uzunluğu ölçümü } \\
\hline Sağ el 2. parmak & $68,31(4,01)$ & $72,83(4,19)$ & $70,12(4,64)$ & $<0,001$ \\
\hline Sağ el 4. parmak & $67,33(3,99)$ & $74,57(4,23)$ & $70,24(5,41)$ & $<0,001$ \\
\hline Sağ el 2./4.parmak oranı & $1,01(0,02)$ & $0,97(0,02)$ & $0,99(0,03)$ & $<0,001$ \\
\hline Sol el 2. parmak & $68,21(3,88)$ & $73,19(4,18)$ & $70,21(4,69)$ & $<0,001$ \\
\hline Sol el 4. parmak & $66,51(3,90)$ & $73,48(4,20)$ & $69,31(5,28)$ & $<0,001$ \\
\hline Sol el 2./4.parmak oranı & $1,02(0,02)$ & $0,99(0,02)$ & $1,01(0,03)$ & $<0,001$ \\
\hline Cinsiyet $[\% /(n)]$ & $59,8(295)$ & $40,2(198)$ & $100(493)$ & \\
\hline \multicolumn{5}{|l|}{ Okuduğu sınıf [\%/(n)] } \\
\hline 1.sinif & $32,2(159)$ & $19,5(96)$ & $51,7(255)$ & \\
\hline $2 . \sin 1 f$ & $21,7(107)$ & $16,2(80)$ & $37,9(187)$ & \\
\hline $3 . \sin 1 f$ & $5,8(29)$ & $4,5(22)$ & $10,3(51)$ & \\
\hline \multicolumn{5}{|l|}{ Anne eğitimi $[\% /(n)]$} \\
\hline Ortaöğretim ve altı & $39,5(195)$ & $27,8(137)$ & $67,3(332)$ & \\
\hline Yükseköğretim ve üstü & $20,1(99)$ & $12,5(62)$ & $32,6(161)$ & \\
\hline \multicolumn{5}{|l|}{ Baba eğitimi [\%/(n)] } \\
\hline Ortaöğretim ve altı & 19,8 (98) & $16,9(83)$ & $36,7(181)$ & \\
\hline Yükseköğretim ve üstü & $39,9(197)$ & $23,4(115)$ & $63,3(312)$ & \\
\hline
\end{tabular}

t-testi, One-way ANOVA) uygulandi. Ayrica Pearson Korelasyon Analizi ile veriler arasındaki ilişki araștırıldı. İstatistiksel anlamll1ı düzeyi $p<0,05$ olarak kabul edildi.

\section{Bulgular}

Çalışmada yaş ortalamaları 19,76 (SS=1,52) olan 493 (295 kadın, 198 erkek) öğrencinin verileri değerlendirildi. $\mathrm{Bu}$ ögrencilerin \%51,7'si $(\mathrm{n}=255)$ 1. sinıf, \%40,2'si ( $n=198)$ erkek, \%67,3'ünün $(n=332)$ anne eğitimi ortaöğretim ve altı, \%63,3’ünün $(n=312)$ baba eğitimi yükseköğretim ve üstü düzeydeydi. Cinsiyetler açısından bakıldığında boy, kilo, VKİ, sağ ve sol el 2. ve 4. parmak uzunlukları erkeklerde, sağ ve sol el 2P:4P oranları ise kadın cinsiyette anlamlı düzeyde yüksek bulundu $(p<0,001)$. Katılımciların boy, kilo, VKİ ve parmak uzunluk ölçümleri ve demografik özellikleri Tablo 1'de gösterilmektedir. Erkek öğrencilerde anlamlı düzeyde yüksek bulunan VKİ ile el 2P:4P oranları arasında istatistiki açıdan anlamlı bir ilişki saptanmadı.

Çalışmada PANAS Cronbach Alfa iç tutarlilık katsay1sı 0,755, BFKE-K Cronbach Alfa iç tutarlilık katsay1s1 0,763 olarak hesaplandi.
Çalışma grubunun PANAS-Pozitif Duygu Puanı Ort. $=30,07$ ve $S S=7,16$; BFKE-K Puan 1 ise Ort. $=97,02$ ve $S S=13,69$ puan olarak belirlendi. Kadinlarda PANAS-Pozitif Duygu Puan 1 Ort. $=29,09$ ve $S S=7,33$, erkeklerde Ort. $=31,53$ ve $S S=6,65$ olarak bulunurken, PANAS-Negatif Duygu Puanı kadınlarda Ort. $=19,33$ ve $S S=6,31$, erkeklerde $O r t .=22,10$ ve $S S=7,75$ olarak tespit edildi ve görüldüğü gibi her iki duygu puanı erkeklerde anlamlı olarak yüksek bulundu $(\phi<0,001)$. BFKE-K alt ölçeklerinden uyumluluk puanı kadınlarda $($ Ort. $=31,71, S S=4,37)$, erkeklere $($ Ort. $=30,31, S S=4,83)$ göre anlamlı düzeyde yüksekti $(\mathrm{p}<0,001)$. PANASPozitif Duygu Puanı 3. sınıf ögrrencilerinde Ort. $=33,41$ ve $S S=7,89$ olarak tespit edildi ve 1 . ile 2 . sinif öğrencilerinin aldıkları puanlardan anlamlı düzeyde yüksek bulundu $(p<0,001)$. Katılımcıların BFKE-K ve alt ölçekleri (Dışa dönüklük, Uyumluluk, Sorumluluk, Duygusal dengelilik-Nevrotiklik, Deneyime açıllık) ortalama puanlar1 sirasiyla Ort. $=97,02, \quad S S=13,69$; Ort. $=24,19, S S=4,75 ;$ Ort. $=31,15, S S=4,61 ;$ Ort. $=29,37$ $S S=5,12 ;$ Ort. $=24,06, S S=5,25$ ve Ort. $=33,52, S S=6,32$ olarak belirlendi. BFKE-K toplam puanı ve dişa 


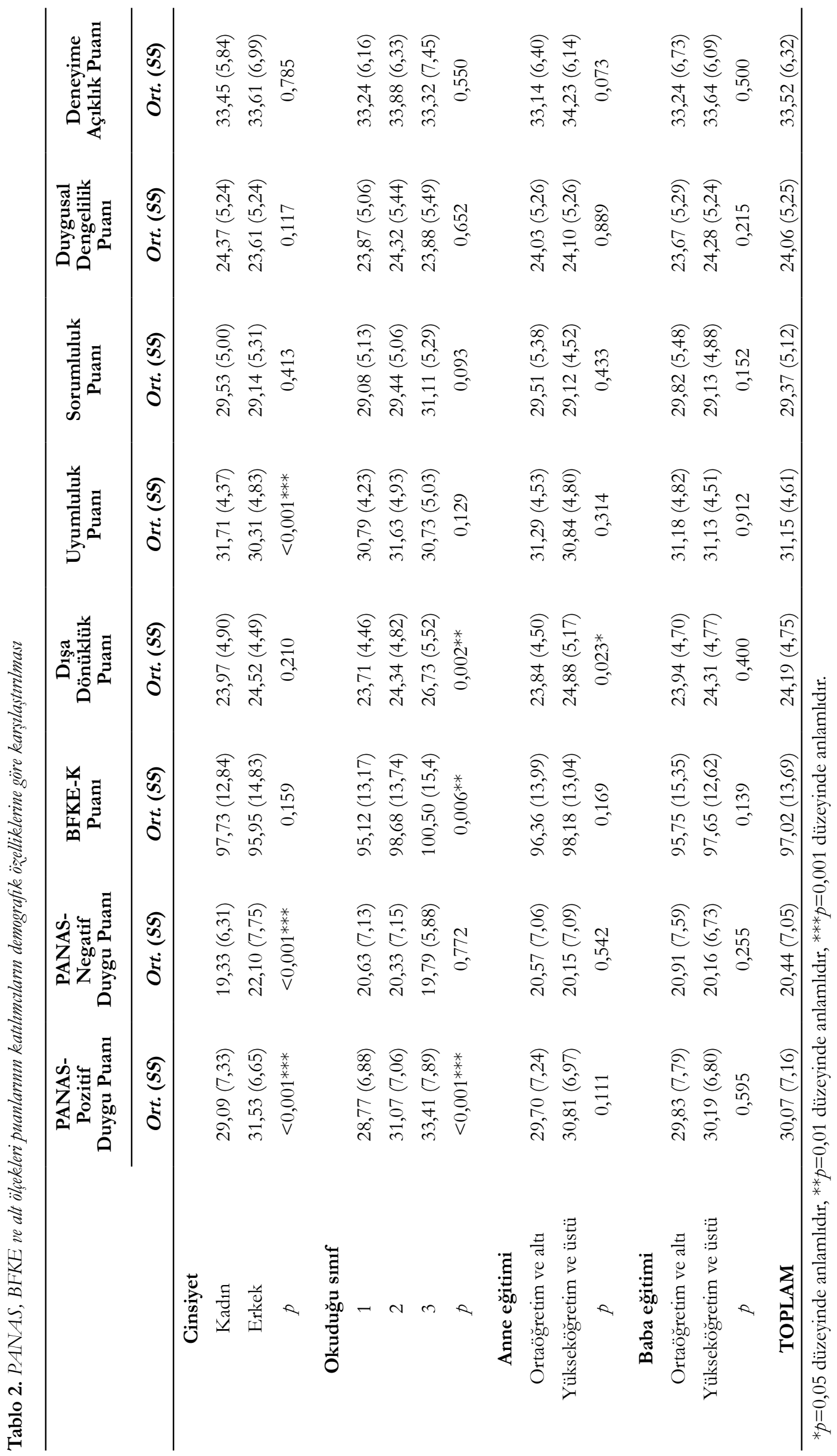




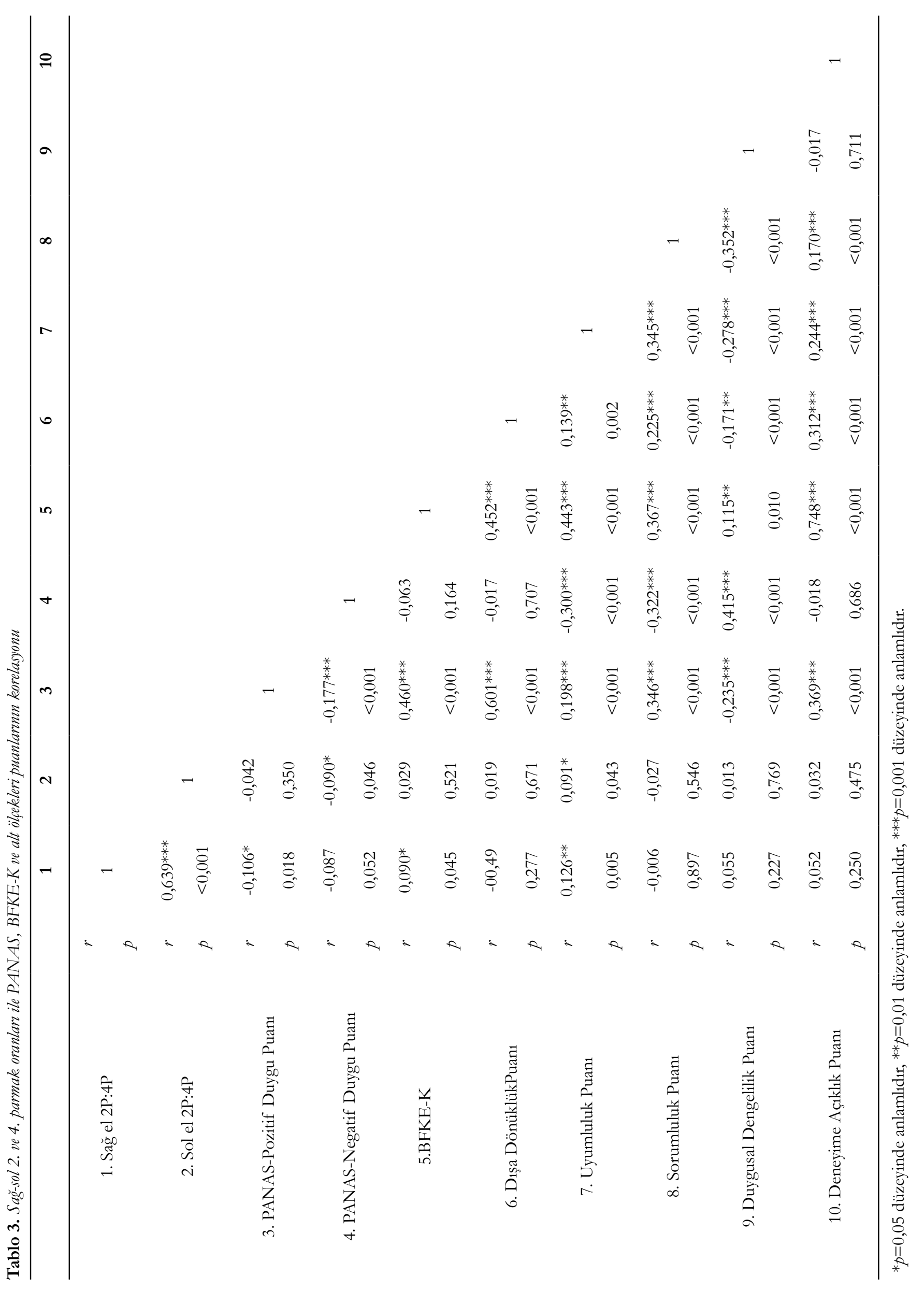


dönüklük puanı 3. sınıf öğrencilerinde Ort. $=100,50$, $S S=15,4$ ve Ort. $=26,73, S S=5,52$ puan olarak hesapland 1 ve 1. ile 2. sınıf öğrencilerinin puanlarına göre anlamlı düzeyde yüksek bulundu (sirasiyla $p=0,006 ; p=0,002$ ). Ayrıca annelerinin eğitim düzeyi yükseköğretim ve üstü olanların dişa dönüklük puanları $O r t .=24,88$ ve $S S=5,17$ puanıly diğer gruba göre istatistikî açıdan anlamlı düzeyde yüksek olarak tespit edildi $(p=0,023)$. Tablo 2'de PANAS, BFKE-K ve alt ölçekleri puanlarının katılımcıların demografik özelliklerine göre karşılaştırılması belirtilmektedir.

Çalışmaya katılan öğrencilerin sağ-sol el 2P:4P oranları ile PANAS ve BFKE-K puanları arasındaki ilişkiyi değerlendirmek için Pearson Korelasyon Analizi yapıldı. Sağ el 2P:4P oranları ile PANAS-Pozitif Duygu Puanı arasinda negatif yönde zayıf korelasyon $(r=-0,106, p=0,018)$, PANAS-Negatif Duygu Puan1 arasında negatif yönde çok zayıf korelasyon $(r=-0,087$, $p=0,052)$ ve BFKE-K Puanı arasında pozitif yönde zayıf korelasyon $(r=0,090, p=0,045)$ saptand1. Sağ el 2P:4P oranının sol ele göre uyumluluk puanı ile daha kuvvetli pozitif korelasyon (sağ, $\imath=0,126, \quad p=0,005$; sol, $r=0,091, p=0,043)$ gösterdiği tespit edildi. Ayrıca, sol el 2P:4P oranları ile PANAS-Negatif Duygu Puanı arasında negatif yönde çok zayıf korelasyon $(r=-0,090$, $p=0,046)$ bulundu. Tablo 3 sağ-sol el 2P:4P oranları ile PANAS, BFKE-K ve alt ölçeklerine ait puanlar arasındaki korelasyonu göstermektedir.

\section{Tartışma}

Antropoloji bilim dalında kullanılan antropometri çok çeşitli sektörlerde kullanılır. Örneğin ergonomi alanında işin insana, insanın işe uyumunu sağlama, temel (anatomi) ve klinik tıp bilimlerinde bazı hastalıkların tanısı ve sağlık hizmetlerinin iyileştirilmesi ve özellikle spor alanında bireyin yatkın olduğu spor dalının belirlenmesine yönelik yapılan çalısmalarda uzun yıllardır faydalanılan bir tekniktir (Akın vd., 2017; Koç ve Çetli, 2019). Literatürde, antropometrik bir ölçüm olan insan el 2P:4P oranının cinsiyet hormon düzeyinin güvenilir bir belirleyicisi olduğu ve bilişsel yetenekler, duygusal zekâ, sayısal/sözel dallara yatkınlık, kişilik özellikleri ve akademik performans ile pozitif ya da negatif anlamlı bir korelasyon gösterdiği belirtilmektedir (Cebe ve Varol, 2017; Özek, 2017). Son yıllarda yapilan çalışmalarda, parmak uzunluk oranları ile kişilik özelliği arasındaki bağıntıların kadınlarda erkeklerden daha güçlü olduğu, erkeklerin kadınlara göre iddialı olma, benlik saygısı, açık fikirlilik, deneyime açılık, heyecan arama boyutlarında daha etkin olduğu belirtilmektedir (Fink vd., 2004; Burton vd., 2013; Tatar vd., 2017). Sahip olunan bilgi birikimi çerçevesinde; eğitim sisteminde bireyin pozitif ve negatif duyguların kontrol edip yönetebilmesi ve öğrencinin bir konuyu nasıl ve ne oranda daha iyi öğrenebileceğinin tespit edilebilmesi için hem bireye özgü fiziksel özelliklerin hem de ilgi, yetenek, zekâ ve kişilik özelliklerinin göz önünde bulundurulması gerekmektedir. Sosyal psikolojide pozitif duygulanımların bireyin ihtiyaç duyanlara yardım olasıllı̆ını artırdığı belirtilmektedir ki bu da bir hekim adayı için çok önemlidir.

Ülkemizde medikal antropoloji alanında yapılan çalışmalara bakıldığında hekimlerin fizikî ve kişilik özellikleri arasındaki ilişkiyi konu alan araştırmaların yok denecek kadar az olması dikkat çekicidir. Hekimin ruh ve beden sağlığı ile bunları etkileyen faktörler arasındaki ilişkinin araştırılması tıbbî alanda gelişmelere olanak verdiği gibi hasta-hekim ilişkisini de optimum seviyelere yükseltir. Hekimlerin kişilik özellikleri, olumlu-olumsuz duygulanımları, empati, anlayış ve özanlayış düzeyleri hasta hekim ilişkisini, sağllk hizmetlerinin kalitesini ve ekonomik yükünü etkileyen önemli faktörlerdir (Karaoğlu ve Şeker, 2011; Deniz vd., 2012; Can, 2017; Özek, 2017). Yine literatürde üniversite öğrencilerinin sağ ve sol el 2P:4P oranları ile kişilik özellikleri, pozitifnegatif duygulanımlarını araştıran bazı çalışmalar olmasına karşın hekim adaylarını konu edinen yayına rastlanamamıştır. $\mathrm{Bu}$ tür çalışmalarda elde edilen verilerle farkındalık oluşturma, eğitimle öğrencilerin bazı kişilik özelliklerini ve duygulanımlarını değiştirebilmek mümkündür (Deniz vd., 2012).

Çalışmada sağ ve sol el 2. ve 4. parmak uzunluklarının erkek öğrencilerde, sağ ve sol el 2P:4P oranlarının ise kız öğrencilerde anlamlı derecede yüksek saptanmış olması literatürdeki çalışma sonuçları ile benzerlik göstermektedir (Fink vd., 2004; Aksu vd., 2010; Burton vd., 2013; Tatar vd., 2017; Cebe ve Varol, 2017). Çalısmamızda cinsiyet hormonlarının ölçüm değerleri ile ilgili bir karşılaştırma yapılmamış olduğundan sadece bulguların genel literatür bilgisi ile uyumlu olduğunu söylemek mümkündür. PANAS-Pozitif ve Negatif Duygu Puanları'nın erkek öğrencilerde kız öğrencilerden anlamlı derecede yüksek olması ve sağ el 2P:4P oranı ile PANAS-Pozitif Duygu Puanı arasinda negatif yönde korelasyon saptanmış olması çalışmanın en önemli bulgularındandır. Her bireyde hem negatif hem de pozitif duygulanımın mevcut olduğu ancak genellikle birinin daha baskın olduğu ifade edilmektedir. Ancak bilinen diğer bir gerçek kadınların duygularını daha rahat ifade edebildikleri, empatik eğilimlerinin daha yüksek olduğudur ve bizim çalışmamızda kız öğrencilerde sağ el 2P:4P oranı erkeklere göre daha yüksek bulunurken PANAS Pozitif Duygu Puanı düşük olarak tespit edildi. Bizim çalışmamızla uyumlu olarak, Aksu ve ekibi (2010) 48 kadın ve 15 erkek üniversite öğrencisinin yer aldığ1 çalışmalarında sol el 2P:4P oranı düşük çıkan grupta dikkatli karar verme, yeniliğe açıklık puanlarının, sağ el 2P:4P oranı düşük olan grupta östrojeni baskın gruba 
göre duyguları değerlendirme, sorumluluk, kararlılık puanlarının daha yüksek olduğunu tespit etmişlerdir. Her iki el 2P:4P oranı düşük çıkan grupta dikkatli karar verme, düzenlilik, sorumluluk, kararll1ık, analitik düşünme ve duyarlılık puanı yüksek bulunmuştur (Aksu vd., 2010). Fink ve ekibinin (2004) çalışmasında tüm bireylerde duygusal dengelilik özelliği să̆ el 2P:4P oran1 ile pozitif korelasyon gösterirken, erkeklerde sol el oranı ile de pozitif ilişki bulunmuştur (Fink vd., 2004). Lippa (2006) 2P:4P oranının deneyime açıklık ile pozitif, dişadönüklük ve uyumluluk (agreeableness) ile negatif korelasyon gösterdiğini, ayrıca nevrotik kişilikle ilişkili olmadığını tespit etmiştir (Lippa, 2006). Özek (2017) Bilgisayar ve Öğretim Teknolojileri bölümündeki 42 kadın ve 46 erkek öğrenci üzerinde yaptığı çalışmada sol el 2P:4P oranı ile öğrenme stillerini anlama boyutu ve sağ el 2P:4P oranı ile öğrenme stillerini işleme boyutu arasında anlamlı bir ilişki bulmuştur (Özek, 2017). Tatar ve ekibi (2017) 18-27 yaş aralı̆̆ında 310 kadın üzerinde yaptığı çalışmada 5 FKE anketini uyguladıktan sonra sağ ve sol el 2P:4P oranlarını tespit ederek aralarındaki korelasyonu bildirmişlerdir.

PANAS-Pozitif Duygu Puanının 3. sinif öğrencilerinde 1. ile 2. sinıf öğrencilerinin aldıkları puanlardan anlamlı düzeyde yüksek olması yüz güldürücüdür. Bu sonuç Puthran ve ekibinin (2016) sonuçları ile uyumludur. Ekip tıp öğrencilerindeki depresyonun prevalansına yönelik 23 ülke de yapılan çalışmaları analiz etmişler ve depresyon için tüm çalışmalarda elde edilen değerlerin ortalamasını \%28 bulmuşlardır (Puthran vd., 2016). Ayrıca, depresyon oranının 1. sınıfta anlamlı ölçüde daha yüksek olurken üst sınıflarda azaldığını ve kadınlarda erkeklere göre daha fazla görüldügünü rapor etmişlerdir (Puthran vd., 2016). Pozitif duygulanım akıl sağlığ1, yeterlik duygusu, sosyal ilişkilerde doyum artışı ile ilişkili olup eğitimle desteklenebilir ve süreğenliğinin sağlanmas1 negatif duyguları dengeler (Karaoğlu vd., 2012; Puthran vd., 2016). Negatif duygulanıma sahip bireylerin öfke, nefret, küçümseme, suçluluk duygusu, korku ve depresyon yaşamaya eğilimli olduğu belirtilmektedir. Pozitif duyguların yeni ve yaratıcı keşiflere, fikirlere teşvik ettiği ve bu yolla fiziksel, entelektüel, sosyal ve psikolojik kaynaklarla gelişen bireyin baş etme ve hayatta kalma becerilerinin de arttığı söylenmektedir (Karaoğlu vd., 2013). Çalışmamızda 3. sınıf öğrencilerinde eğitim süreci zorluğunun artışına karşın pozitif duygulanımda artış görülmesi eğitimle bu duyguların desteklenerek arttır1labileceğini göstermektedir. Ayrıca, demografik özellikler arasında yer alan anne eğitim düzeyi, yükseköğretim ve üstü olanların dişa dönüklük puanı (Ort. $=24,88, \mathrm{SS}=5,17$ ) diğer grubun puanına göre istatistiki açıdan anlamlı düzeyde yüksek olarak bulundu $(p=0,023)$. Elde ettiğimiz bu veri, bize kişilik özellikleri üzerindeki çevre etkisinin önemini göstermektedir.
Pozitif duygulanım hekim-hekim ve hekim-hasta ilişkilerinin sağlıklı ve dengeli olması açısından oldukça önemlidir ve profesyonel olmalarını beklediğimiz hekim adaylarının sağlık hizmeti kaynaklarını verimli bir şekilde kullanmasını sağlar (Karaoğlu vd., 2013).

Cebe ve ekibinin çalışmasına benzer olarak elde ettiğimiz sonuçlar el 2P:4P oranının kişilik özelliklerini belirlemede etkin olduğunu göstermektedir (Cebe ve Varol, 2017). Bu konuda farklı yöntemler kullanılarak yapılacak çalışmalar preklinik tıp öğrencilerinin el 2P:4P oranına bakilarak hangi uzmanlık alanlarına yatkın olduklarının tespit edilebilmesine ve buna uygun bir eğitim sistemi oluşturularak bireylerin kariyer hedeflerini bu yönde planlamalarına imkan sağlayacaktır. İnsan sağllğının korunması ve tedavi edilmesi alanlarında sağlık hizmeti sunan hekimlerde akademik performansın artması tup bilişimi alanında biyomedikal bilginin saklanması, ulaşılması ve yönetimini daha etkin ve hızlı olmasına katk1 sağlayacaktır. Üniversite öğrencileri ile yapılan çalışmalar nevrotiklik, gelişime açıklık, uyumluluk ve öz disiplin/sorumluluk ile akademik performans arasında olumlu bir ilişki olduğunu ifade etmektedir (Fink vd., 2004; Aksu vd., 2010; Burton vd., 2013; Tatar vd., 2017; Cebe ve Varol, 2017).

Çalışmaya sadece 1. ve 2. sınıf tıp öğrencilerinin dâhil edilip üst sınıfların davet edilmemesi çalışmamızı sınırlandırmıştır. Bu kısıtlılık, yaş aralığının daralmasına neden olmuştur. Ayrıca, az sayıdaki 3. sınıf öğrencilerinde dışa dönüklük puanının diğerlerinden daha yüksek bulunması göz önüne alındığında üst sınıfların dâhil edildiği bir çalışmanın daha anlamlı sonuçlar verebileceği düşünülmektedir.

\section{Sonuç}

Sağlık, bireyin kendisiyle barışık olması, sorumluluklarını yerine getirmesi ve sosyokültürel sorunlarla başa çıkabilmesidir. Hastalık ise sağlığın süreğenliğindeki kalıcı ya da geçici bozulmadır ve tedavisine ilişkin uygulamalarda insanın kissilik, davranış ve deneyimlerini etkileyen faktörler gözönünde tutulmalıdır. Sağlık ve hastalıkların oluşumuna neden olan faktörleri hem tıbbî hem de kültürel bir bakış açısı ile ele alan uygulamalı medikal antropoloji, hastalıkların önlenmesi ve tedavi edilmesini hedefleyen tıp alanında oldukça önemli bir yere sahiptir. Medikal antropoloji alanında yapilan çalışmaların oluşturduğu farkındalıklar sayesinde doktor adayına yetenek, yatkınlık ve kişilik özelliklerine uygun daha iyi bir tıp eğitimi verilebilir. Sağlıklı hasta-hekim ve hekim-hekim ilişkisi hastalıkların tanı-tedavi sürecine ve tıbbî bilgi üretimine olumlu düzeyde katk1 sağlar.

Sağlığın korunması ve hastalıkların önlenmesinde birincil derecede görev alacak hekim adaylarını içeren bu çalışmamızda elde ettiğimiz veriler, cinsiyetin sekonder göstergesi olan el parmak antropometrisi ile kişilik özellikleri arasında önemli ölçüde bir korelasyon 
olduğunu göstermektedir. Bu verilerin, preklinik tıp ögrencilerinde el parmak uzunlukları oranı ile kişilik özellikleri ve pozitif-negatif duygulanımlar arasındaki ilişkiyi konu alan ya da ilgili olan çalışmalara bir veri tabanı oluşturmasını ve bu konuda bir farkındalık oluşturarak daha geniş çapta ve farklı özellikleri içeren araştırmalara yol göstermesini umuyoruz.

\section{Kaynakça}

Akın, G., Özkoçak, V., ve Gültekin, T. (2017). Somatoskopi ve antropometri tekniklerinin adli bilimler için önemi. Hitit Üniversitesi Sosyal Bilimler Enstitüsü Dergisi, 10(2), 703-714. https://doi.org/10.17218/hititsosbil.328735

Aksu, F., Tatar, A., Türkmen, S., Çelikli, S., Çelik, A., ve Tetik, S. (2010). Paramediklerde psikolojik değerlendirme ve eldeki 2/4 parmak oranının kişilik yapısı ile ilişkisi. DEÜ Tıp Fakültesi Dergisi, 24(1), 11-18.

Burton, L. A., Guterman, E., ve Baum, G. (2013). Effect of prenatal androgen on adult personality: greater openness with more female-typical 2D: 4D digit ratios. Current Psychology, 32, 197-202. https://doi.org/10.1007/s12144-013-9170-9

Can, B. (2017). T1bbi Antropoloji niçin önemlidir? Toplum ve Hekim, 32(4), 316-320.

Cebe, B., ve Varol, A. (2013). 2D:4D parmak uzunlukları oranı ile kişilerin sayısal-sözel dallara yatkınlıkları arasındaki ilişkinin uzman sistem ile tespiti. Türkiye Bilişim Vakefı Bilgisayar Bilimleri ve Mühendisliği Dergisi, 6(1), 1-10.

Demirci, Ö. E., ve Öztop, D. B. (2015). Dikkat eksikliği hiperaktivite bozukluğu olan erkek çocuk ve ergenlerde agresyon, empati ve 2p:4p parmak oranlarının ilişkisi. Yeni Symposium, 53(3), 1-9. http://yenisymposium.com/Pdf/TR-YeniSempozyum2b9f9e64.pdf

Deniz, M. E., Arslan, C., Özyeşil, Z., ve İzmirli, M. (2012). Özanlayış, yaşam doyumu, negatif ve pozitif duygu: Türk ve diğer ülke üniversite öğrencileri arasında bir karşılaştırma. Mehmet Akif Ersoy Üniversitesi Eğitim Fakülttesi Dergisi, 12(23), 428-446.

Fink, B., Manning, J. T., ve Neave, N. (2004). Second to fourth digit ratio and the big five personality factors. Personality and Individual Differences, 37(3), 495-503. https://doi. org/10.1016/i.paid.2003.09.018

Gençöz, T. (2000). Pozitif ve negatif duygu ölçeği: Geçerlik ve güvenirlik çalışması. Türk Psikoloji Dergisi, 15(46), 19-26.

Goldberg, L. R. (1992). The development of markers for the Big-Five factor structure. Psychological Assessment, 4(1), 26-42. https://doi.org/10.1037/1040-3590.4.1.26

John, O. P., Srivastava., S. (1999). The Big-Five trait taxonomy: History, measurement, and theoretical perspectives. L. A. Pervin ve O. P. John (Ed.) içinde, Handbook of personality: Theory and research, Vol. 2 (s. 102-138). Guilford Press.

Karaoğlu, N., ve Şeker, M. (2011). Klinik öncesi yıllardaki tıp öğrencilerinin anksiyete ve depresyon düzeyleri ve etkili olabilecek faktörler. TAF Preventive Medicine Bulletin, 10(3), 303-312. https://www.bibliomed.org/ mnsfulltext/1/1-1278848350.pdf?1610541821
Karaoğlu, N., Batı, A. H., Şenol, Y., Naçar, M., Özer, A., ve Altıntaş, L. (2012). Türkiye'de tıp eğitimi tıp öğrencilerinin yalnızlık, anksiyete, depresyon düzeylerini ve empatik eğilimlerini etkiliyor mu? Tip Eğitimi Dünyası Dergisi, 34, 13-18.

Karaoglu, N., Pekcan, S., ve Y1lmaz, S. (2013). Are problem based scenarios supporting the positive affect and empathy of medical students? Procedia - Social and Behavioral Sciences, 82(3), 101-107. https://doi.org/10.1016/j.sbspro.2013.06.231

Koç, F., ve Çetli, E. (2019). Parmak oranlarının (2P:4P) sağlık bilimleri alanında kullanımı, Ş. Gerçek, T. Demirci ve V. Özkoçak (Ed.) içinde, Current Debates in Social Sciences (s. 6-11). IJOPEC Publication. http://www.ijopec.co.uk/wp-content/ uploads $/ 2020 / 01 / 2019$ 21.pdf

Lippa, R. A. (2006). Finger lengths, 2D:4D ratios, and their relation to gender-related personality traits and the Big Five. Biological Psychology, 71(1), 116-121. https://doi.org/10.1016/i. biopsycho.2005.02.004

Lutchmaya, S., Baron-Cohen, S., Raggatt, P., ve Knickmeyer, R. (2004). 2nd to 4th digit ratios, fetal testosterone and estradiol. Early Human Development, 77(1-2), 23-28. https:// doi.org/10.1016/i.earlhumdev.2003.12.002

Malas, M. A., Dogan, S., Evcil, E. H., ve Desdicioglu, K. (2006). Fetal development of the hand, digits and digit ratio (2D:4D). Early Human Development, 82(7), 469-475. https://doi. org/10.1016/j.earlhumdev.2005.12.002

Manning, J. T. (2011). Resolving the role of prenatal sex steroids in the development of digit ratio. PNAS, 108(39), 16143-16144. https://doi.org/10.1073/pnas.1113312108

Mitsui, T., Araki, A., Miyashita, C., Ito, S., Ikeno, T., ve Sasaki, S. (2016). The relationship between the second-to-fourth digit ratio and behavioral sexual dimorphism in schoolaged children. PLOS ONE, 11(1), e0146849. https://doi. org/10.1371/journal.pone.0146849

Özek, M. B. (2017). Böte bölümü öğrencilerinin 2d/4d parmak oranları ile öğrenme stilleri ve duygusal zekaları arasındaki ilişkinin belirlenmesi. Diyalektolog Ulusal Sosyal Bilimler Dergisi, 16, 115-126. https://doi.org/10.22464/divalektolog.156

Özkan, G., Akkoç, R. F., ve Ögetürk, M. (2018). İkinci ve dördüncü parmak oranının (2p:4p) tip-2 diabetes mellitus ile ilişkisi. F.Ü. Sağhle Bilimleri Tip Dergisi, 32(1), 1-5. http://tip.fusabil.org/ pdf/pdf FUSABIL 1253.pdf

Puthran, R., Zhang, M. W., Tam, W. W., ve Ho, R. C. (2016). Prevalence of depression amongst medical students: a meta-analysis. Medical Education, 50(4), 456-468. https://doi. org/10.1111/medu.12962

Putz, D. A., Gaulin, S. J. C., Sporter, R. J., ve McBurney, D. H. (2004). Sex hormones and finger length: What does 2D:4D indicate? Evolution and Human Behavior, 25(3), 182-199. https:// doi.org/10.1016/i.evolhumbehav.2004.03.005

Tatar, A., Özmen, H. E., ve Aksu, F. (2017). Genç kadınlarda eldeki 2./4. parmak uzunluk oranına göre kişilik özellikleri profilinin incelenmesi. Nobel Medicus, 13(1), 39-47. https:// www.nobelmedicus.com/Content/1/37/39-47.pdf

Ulcay, T., ve Kamaşak, B. (2020). Tip fakültesi öğrencilerinde kraniyofasiyal antropometrik ölçümlerin cinsiyete bağlı karşılaştırmalı incelenmesi. Antropoloji, (39), 66-73. https:// 
doi.org/10.33613/antropolojidergisi.731186

Vladeanu, M., Giuffrida, O., ve Bourne, V.J. (2014). Prenatal sex hormone exposure and risk of Alzheimer disease: A pilot study using the $2 \mathrm{~d}: 4 \mathrm{~d}$ digit lenght ratio. Cognitive and Behavioral Neurology, 27(2), 102-106. https://doi.org/10.1097/ WNN.0000000000000024

Wilson, G. D. (1983). Finger-length as an index of assertiveness in women. Personality and Individual Differences, 4(1), 111-112. https://doi.org/10.1016/0191-8869(83)90061-2

\section{(c) (1) (8) \\ BY NC 2021. Telif haklar1 yazar(lar)a aittir.}

Bu makale Creative Commons Atıf-GavriTicari 4.0 Uluslararas1 (CC BY-NC 4.0) lisansının hüküm ve şartları altında yayımlanan açık erişimli bir makaledir. 